\title{
Roda de Conversa: Arranjo Disparador da Participação do Trabalhador na Implementação das Diretrizes da Política Nacional de Humanização no Ambiente Hospitalar
}

\author{
Castro, Adriana Miranda de; Pereira, Carlos Roberto Pinto; Thomazinho, Paula de \\ Almeida \\ Fundação Oswaldo Cruz — drikamcastro@gmail.com
}

Introdução: a incorporação da Política Nacional de Humanização (PNH) como diretriz para a reestruturação da gestão e qualificação da atenção prestada em ambiente hospitalar apresenta inúmeros desafios. por constituir-se num conjunto de ações sobre diversas práticas em diferentes níveis de prestação de serviço e do próprio Sistema, prima por formar e fortalecer a construção coletiva de todos os atores envolvidos. o processo foi iniciado em uma unidade hospitalar com a dissolução do grupo técnico de humanização existente há alguns anos na instituição e a realização de oficinas de sensibilização e grupos de trabalho, que elencaram os dispositivos prioritários e com maior possibilidade de êxito para mobilizar a transformação institucional. Naquele momento, o foco do trabalho fixou-se na implantação de colegiados de gestão a fim de deslocar a deliberação sobre o cotidiano do trabalho do profissional médico e de fortalecer a construção de equipes multiprofissionais. Paralelamente, por iniciativa de um grupo de trabalhadores criou-se a Roda de Conversa, objetivando: ampliar a compreensão da $\mathrm{PNH}$, acompanhar a efetividade e impacto das suas diretrizes no hospital e garantir um espaço aberto de reflexão crítica do trabalhador sobre a organicidade da humanização no dia-a-dia. Objetivo: Analisar a potência da Roda de Conversa como dispositivo de gestão participativa e de sustentabilidade da implementação das diretrizes da PNH no âmbito hospitalar. Método: Sistematização do funcionamento e análise das atas das reuniões da Roda de Conversa no período de 2011/ 2013, descrição do cenário macroestrutural do hospital, cotejamento das pautas e reflexões dos trabalhadores na Roda às deliberações da gestão da unidade e aos avanços e resistências identificados quanto à implantação dos dispositivos da $\mathrm{PNH}$, notadamente o colegiado de gestão. Resultado: a Roda de Conversa sempre buscou ser espaço protegido para acolher o trabalhador e colocá-lo no protagonismo da gestão do trabalho, mas obteve significados diversos ao longo dos anos. Primeiro, caracterizouse pela problematização do funcionamento dos colegiados e seus efeitos, da dificuldade em descentralizar o poder e coletivizar as decisões quanto ao trabalho, da reestruturação organizacional e das funções de gerências multiprofissionais e compartilhadas. a seguir vê-se um esfriamento do debate e a redução da participação, que levam à proposição da Roda como espaço de educação permanente sobre temáticas críticas da PNH no âmbito do hospital e boas práticas em humanização. Conclusão: Entende-se que a Roda mostrou-se ferramenta interessante no fortalecimento da decisão da gestão quanto à implantação da $\mathrm{PNH}$ : capilarizando o debate sobre o processo de trabalho, potencializando os trabalhadores na compreensão e participação dos colegiados de gestão, resistindo às tentativas de cooptação e desmonte do projeto de humanização e formando criticamente quanto aos princípios, método e diretrizes da PNH.

Castro, Adriana Miranda de; Pereira, Carlos Roberto Pinto; Thomazinho, Paula de Almeida. Roda de Conversa: Arranjo Disparador da Participação do Trabalhador na Implementação das Diretrizes da Política Nacional de Humanização no Ambiente Hospitalar. In: Anais do Congresso Internacional de Humanidades \& Humanização em Saúde [= Blucher Medical Proceedings, num.2, vol.1]. São Paulo: Editora Blucher, 2014. ISSN 2357-7282 DOI 10.5151/medpro-cihhs-10251 